\title{
Anthropological Engagements with Development
}

\section{Tania Murray Li}

\section{(2) OpenEdition}

\section{Journals}

Electronic version

URL: http://journals.openedition.org/anthropodev/495

DOI: 10.4000/anthropodev.495

ISSN: 2553-1719

Publisher

APAD - Association pour l'anthropologie du changement social et du développement

\section{Printed version}

Date of publication: 1 April 2014

Number of pages: $227-240$

ISBN: 979-10-93476-00-1

ISSN: 2276-2019

\section{Electronic reference}

Tania Murray Li, « Anthropological Engagements with Development », Anthropologie \& développement [Online], 37-38-39 | 2014, Online since 01 December 2016, connection on 14 September 2020. URL : http://journals.openedition.org/anthropodev/495

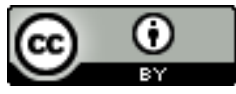

La revue Anthropologie \& développement est mise à disposition selon les termes de la Licence Creative Commons Attribution 4.0 International. 


\title{
Anthropological Engagements with Development ${ }^{1}$
}

\author{
Tania Murray Li
}

I propose to distinguish 3 types of anthropological engagement with development, each with own set of fieldwork relations, and characteristic tensions. I'll also argue that these three types are not compatible - they don't connect sequentially and aren't usually conducted simultaneously. Hence the importance of situating ourselves and our practices within this milieu.

- $\quad 1 /$ Anthropology in the service of programming or big " $D$ " development (Hart, 2009).

- 2/ Anthropology as a critical engagement with programming.

- $\quad 2 /$ Anthropology as study of historically specific conjunctures, their tendencies and frictions, and the political struggles that emerge from them, i.e. small " $d$ " development.

The first - anthropology in the service of programming - I understand broadly under the rubric of "governing" elaborated by Foucault, or what I called in my book "the will to improve" (Li, 2007). This is the attempt to intervene in social, economic, ecological and other processes to adjust or redirect them in an "improving" direction (Foucault, 1991a). I'll call this practice "programming," and highlight the particular kind of knowledge it requires. Programmers include people working for transnational agencies, government departments, and NGOs, as well as the specialists and consultants (including anthropologists) who support them. The second type of anthropological engagement - critique - is intrinsically linked to the first. It consists in the constant, vigilant questioning of government. What are we trying to govern? Do we have the right object, or the most effective technique? Are we governing too little or too much? How are our attempts to

\footnotetext{
${ }^{1}$ Keynote lecture, APAD International Conference Fieldwork Relations in the Context of Development or Emergency, Montpellier 13-15 June, 2013.
} 
govern working out in practice? Critique also demands a particular kind of knowledge. The third, which we could call ethnography as such, is not connected to programming. It is the attempt to understand the world as it is, in all its diversity, complexity and flux. I will now discuss each of these forms of engagement in more detail.

\section{Fieldwork in the service of programming}

The conference theme is "fieldwork relations in the context of Development or Emergency." These are contexts defined by an urgent need. Someone needs to do something: to intervene, to solve a problem, or to make an improvement. Intervention demands its own form of knowledge, which is produced through two practices. The first is problematization, that is identifying deficiencies that need to be rectified. The second is what I call "rendering technical," a shorthand for the set of practices concerned with representing "the domain to be governed as an intelligible field with specifiable limits and particular characteristics... defining boundaries, rendering that within them visible, assembling information about that which is included and devising techniques to mobilize the forces and entities thus revealed." (Rose, 1999 : 33)

Identifying the problem to be solved and rendering it in technical terms is often quite straightforward in the context of emergency, where immediate needs come to the fore. In relation to development, different lacks and deficiencies could be identified, e.g. poverty, weak infrastructure, low productivity, corrupt institutions, lack of voice and choice, poor hygiene, nutrition, or low environmental awareness. Hence with development, there is always room for debate about which problems are more or less urgent, which are cause and which effect, and how best to rectify them.

Often problem and solution travel together, so a problem-diagnosis already anticipates the prescription-solution that a programmer has in mind, or can feasibly propose to a funding agency. For example, if the problem identified is "poverty," an agricultural development program may specify

${ }^{2}$ I adapt the term "rendering technical" from Rose (p. 79). He glosses it as making something - his example is bonds of solidarity - "amenable to technique." See also Ferguson, 1994. 
"low productivity" as the cause of that poverty, and propose to introduce new seeds and irrigation techniques. Poverty is "rendered technical" in terms the anticipated intervention can actually address. Landlessness, although often recognized as a source of rural poverty, cannot be resolved by means of better seeds or irrigation, so it does not figure in this diagnosis/prescription chain.

Anthropologists who are responsible for programming, whether as program managers or consultants, have to engage in the practices of problematization and rendering technical. Furnishing the relevant kinds of knowledge is a professional requirement, a competence necessary to do the job. The characteristic tension for the anthropologist-as-programmer is mainly internal to the anthropologist. We have to translate our dense, situated knowledge of people, places, and processes into a technical matrix of a manageable, fundable kind. This may do violence to the relations we have built up through our fieldwork, but mainly we are betraying our own complex knowledge - no doubt for a good cause.

I became aware of this kind of betrayal when I undertook a consultancy concerning land rights in Indonesia for the Canadian development agency when it was considering an intervention in this field. The requirements of programming had a visceral effect on me. I realized that I would have to work backwards: first I had to identify a plausible intervention within the scope of agency expertise, and only then should I select and compile the data and analysis that would support it. I did this in consultation with allies in the land rights movement who have lots of experience with this matter. They know how to push boundaries, opening up the terrain for progressive politics (creating an ant path, as they put it), while operating within the lines of intelligibility of transnational donors or government departments. Nevertheless, the constraints are severe. If we admit too much detail, or highlight the role of forces a development agency cannot control, our reports will be shelved. So there is an art to this, and a necessary complicity: it takes a particular kind of fieldwork to construct a technical matrix with a plausible, fundable, problem/solution chain, and to defend it with relevant data. David Mosse's book Cultivating Development (2005) describes in detail the kinds of relations, compromises, and complicities involved. 


\section{Anthropology as critique}

When we analyse the work of programming, as I did in The Will to Improve, we make routine practices of problematization and rendering technical visible, and we expose them for critical scrutiny. Critique is intrinsic to governing, as Foucault explained: there is a constant back and forth between the work of devising governmental interventions, and the work of questioning their diagnoses and prescriptions. Nevertheless, fieldwork in service of critique often creates tense relations, because critique may be interpreted as hostility or an attempt at demolition. It may also be interpreted as a statement about competence, as if the critic is claiming to understand processes that programmers and project insiders can't see. In place of a battle of competencies, I see this as a matter of positioning. The job of the anthropologist as programmer requires simplification and rendering technical. It is probably a personal requirement too - part of how development programmers get themselves to sleep at night. Faced with overwhelming need, urgency and complexity, programmers fix on a kind of intervention that is within their grasp. "At least we're doing something useful - or we're trying " (Mosse, 2011). Critique produces discomfort and defensive reactions: Are you indifferent to suffering? If not, you should get off your high horse and come and help us. Or, you shouldn't criticize if you don't have a solution.

Development agencies are accustomed to the criticism that their interventions only pretend to do good, but are really a cover for exploitation and domination. I do not make this assumption. I take the will to improve seriously: I believe that many development programmers really do want to improve the world. The world is full of interventions that cannot be understood through the optic of domination or profit: interventions to build community institutions, to improve local livelihoods, health and hygiene, and to make planning more participatory and democratic are examples. To examine this type of intervention critically, we need a different focus, one with different implications for fieldwork relations and practices.

I will illustrate by summarizing one of the interventions I examined in my book: a massive, billion dollar intervention designed by anthropologists in the social development team at the World Bank in Jakarta. The program had an exceptionally ambitious goal: to transform Indonesian society from 
the bottom up. It started with very detailed ethnographic studies of Indonesian village life. It was far removed from the clumsy, insensitive, top down approach we often associate with the World Bank or other bilateral agencies. But these were ethnographies of a particular kind. To connect in a useful way to the will to improve, these studies had to come up with a diagnosis/prescription chain in which the Bank could plausibly play a role. They had to identify technical problems for which the Bank could supply technical solutions. Anticipating that the "social development" team would find its technical mission in the improvement of "society," the problem the Bank-sponsored ethnographies identified was the poor quality of village level development planning: corruption, lack of transparency, and lack of participation. These deficiencies resulted in a misconnect between what people wanted, and what the Indonesian government was giving them. To bridge that gap, the Bank set out to reform village level planning. The idea was to build on the natural social capital and customary capacities to be found in Indonesian villages, restore it, optimize it, and turn it to new ends.

Despite their emphasis on local social capital, in practice the Bank social development team came up with a thick rule book that set out in detail the procedures to be followed. The rules were carefully crafted as the social development experts set out to transform old, delinquent practices and replace them with new and improved ones. Every element in the rule book had an educative purpose. The idea was that people would learn new practices, see how well they worked, and then adopt them as their own. The incentive was access to project funds. For example, villagers had to engage in an intensely managed, competitive process in order to access funds for village infrastructure. The idea was that participation in such a process would impart new planning skills. More specifically, since the competition favoured the most "pro-poor" proposals, villagers would learn to think creatively about what kinds of infrastructure actually serve the poor. Another requirement of the program was to post the project budget on the wall of the village meeting hall so that everyone could see how much money had been allocated and check on implementation. From this practice, villagers would learn to think of project funds as an entitlement, bestowed on them collectively to be used for the common good, not as gifts or favours that could disappear as erratically as they arrived. Bank experts also carried out studies to examine the culture of corruption, and devised inter- 
ventions to change villager's views on what was and wasn't acceptable. They supplemented their cultural approach with a tactic drawn from institutional economics, attempting to change the incentive structure by increasing the costs and risks, and reducing the rewards. The idea was to rebalance the equation so that corrupt behaviour would no longer be rational. Through these interventions and others, Bank programmers exercised a will to improve at an extraordinary level of detail. They delved into the minutiae of village life to educate desires, introduce new practices, and transform conduct.

Not surprisingly, their program didn't work quite as planned. Rules were circumvented. But there were some changes. The most beneficial change was the open budget. Due to Bank transparency rules, for the first time villagers knew exactly how much money was allocated for a project such as road building, so if the promised road wasn't completed, they knew how much money had been stolen. Spurred by the sense of indignation their new knowledge enabled, they mobilized to demand redress, transforming themselves from passive victims to active citizens aware of their rights, and empowered to demand them. But their capacity to achieve redress was limited by the stubbornly unequal political and economic relations that continue to dominate Indonesian village life. ${ }^{3}$

My critique of the program went to the heart of its technical matrix, its diagnosis-prescription chain. I argued that this project, financed by a billion dollars of loan funds which Indonesians would have to repay, ran under the label poverty reduction. But it did not address the ongoing processes that produce poverty in Indonesia, such as the grabbing of customary land by Indonesian elites, backed by the military and transnational capital, for use in mining, timber extraction or plantation development. Even routine poverty was not affected by this program. A landless person is not helped by a project to build a farm access road, since he or she doesn't have a farm. Even impeccably democratic procedures for village level development planning would not help this person, because land distribution, or

3 See, for example, the mobilization over a road I describe in Land's End: Capitalist Relations on an Indigenous Frontier (2014). 
better wages, are not on the menu. The extent and distribution of poverty, and the processes that produce it, remain unchanged.

My critique - pointing out a massive gap between what the program claimed to do (reduce poverty) and what it actually did (improve procedures for village planning) - was troubling to the Bank's programmers because they could not respond to it. They knew all too well that they could not address difficult political economic issues like land distribution or resource grabs: national sovereignty, diplomatic etiquette, and the entire idiom of development "partnerships" made that impossible. The tension between World Bank anthropologists-as-programmers and a universitybased anthropologist as critic, all of us similarly trained, produced an impasse. I could respect the Bank anthropologists' professional expertise and admire their fortitude and skill, but I could not agree that they were leaders in poverty reduction because their program design, and the structural position of the World Bank in Indonesia, made that an impossible goal.

One project insider suggested that I should have done more fieldwork. I should have spent time with the Bank team in their meetings and observed their backroom debates and negotiations. I should not have paid so much attention to project documents. Didn't I know that documents are just words, artifacts that must be produced to get project funds flowing? But, I responded, without those documents, and the technical matrix which proposed that problem A plus intervention B would lead to $C$, a beneficial result, there would not have been a flow of a billion dollars in loan funds to Indonesia. Whether or not the goals were achieved, the matrix by itself was already an intervention. As Foucault readily admitted, nothing happens as laid down in programmer's schemes. Yet, he insisted, "they are not simply utopias in the heads of a few projectors." They are not "abortive schemas for the creation of a reality. They are fragments of reality." They "induce a whole series of effects in the real." They "crystallize into institutions, they inform individual behavior, they act as grids for the perception and evaluation of things." (Foucault, 1991b : 81-82). They are, in short, never "just words."

To deepen the dialogue between differently situated anthropologists, I could also have pointed to the experience of David Mosse, who wrote about the back-room work of anthropologists-as-development experts, a 
world in which he participated for several years. He described how he and his colleagues in a project team produced smooth narratives and policy coherence out of the messy realities that confronted them. He pointed out that they had to do this not just to keep their jobs, but to keep the funds flowing so that beneficial results could continue to be produced. Mosse wrote about this world from his position as a former project insider. He received permission from his former colleagues to switch hats and become a researcher, but in the end his colleagues were furious. He wrote a brilliant essay about this - about the tension between fieldwork practices that demand rapport, trust and confidence, and the necessary breach of those relations when the researcher distances him or herself, in order to write about what he found (Mosse, 2006). To analyse his formerly shared, practitioner world, Mosse had to separate himself from it. His former colleagues, for their part, wanted to reabsorb him back into the group so he and they would once again devise an acceptable narrative together, just as they had done when they were writing reports for the project funders. His refusal to do this left them feeling exposed and betrayed. So this is one kind of incompatibility: it is difficult and probably impossible to be part of a project team and write about it ethnographically. Whatever the insider-turnedoutsider writes will likely be understood as an unhelpful disclosure that jeopardizes the project future. It will be viewed as a betrayal not just of collegial relations, but of the will to improve: a sign that the insider-turnedoutsider does not care about the fate of poor people, since $s /$ he does not support the people who try to help them.

Another, more serious incompatibility concerns the relation between programming and critique. Programmers tolerate critique only so long as it can be translated back into programming, or used for the "improvement of improvement," as I called it in my book. Critique that identifies structural problems that development agencies cannot address is generally regarded as unhelpful, unrealistic, and hence without value. Yet I argue that critique is valuable in itself, and a distinct role for anthropologists as critics must be defended. "Critique," argues Foucault (1991b: 84), "doesn't have to lay down the law for the law. It isn't a stage in programming. It is a challenge directed to what is." Zygmunt Bauman (2007) argues this point passionately: unless we are satisfied with the way things are, he insists, we must be critics. Critique, from his perspective, is a political stance that is broadly 
distributed, not one limited to scholars or experts with new programs to propose. Hence not all critique can be absorbed into a new program, nor should it be. If it is, we should sound the alarm: it would mean that the anthropologist as critic is not doing a sufficiently rigorous or serious job.

What, then, can we do about the incompatibility between programming and critique? The answer cannot be to abandon either role: programmers and critics produce different forms of knowledge, both of which have value. As I explained earlier, a central feature of programming is the requirement that problems be framed in terms amenable to technical solutions. This isn't a deficiency. It has to be so. Programming demands closure: a decision to dig in here, to tackle one problem, and set another aside. But the opening up that is intrinsic to critique can only be accomplished when the demands of programming are suspended, at least for a while. We can agree on a respectful division of labour. Or, the same anthropologist can be both a programmer and a critic, so long as she or he keeps the roles distinct, and does not try to occupy them at the same time. Many of us have two hats, which we wear on different days of the week, or at different periods in our careers. Rich insights can be gleaned from boundary crossings such as the one engaged in by David Mosse. Indeed, one of the most important insights from his study was to expose the boundary separating his two distinct worlds, a boundary important enough that it was vigorously defended by anthropologists on both sides of the divide.

How then does the anthropologist-as-critic respond to the challenge that $s /$ he is cold or cynical, lacking in compassion for people who are suffering, and unwilling to help devise programs to improve their lives? My response to this challenge is that programming is important, but it isn't the only source of social change. So what else is there? This question brings me to the third type of anthropological engagement with development. 


\section{Anthropology as study of historically specific conjunctures, and the politics that emerge from them, i.e. small "d" development}

Our training as anthropologists gives us the skills to examine the processes that produce poverty, violence, or other emergencies, in all their complexity and their situated specificity. This is work we must sustain. Poverty isn't a static condition - it is continuously produced, and sometimes reduced in varied and dynamic ways, many of which are outside the scope of development programming. For example, a shift in world prices for particular crops can create a new wave of impoverishment, or bring prosperity, depending on what farmers are growing, and the kinds of productive and extractive relations in which they are involved. Without an understanding of the processes that are producing poverty in a particular time and place, it isn't possible to devise interventions to that would actually reduce it. Yet development programmers, constrained as they are to find technical points of entry for their programs, seldom do this kind of analysis.

Our training as anthropologists also equips us to explore the terrain of politics, broadly conceived. This means examining the social forces that reproduce inequality, and the social forces that might disrupt it. What are the relevant social groups? What are their interests, alliances, and fractures? Which groups would mobilize to change the status quo, and which would mobilize to defend it? Every conjuncture has potential openings, lines of possibility that can be identified and expanded. Yet I seldom see this kind of analysis in development policy documents. They propose that governments should do this, or communities should do that, with little analysis of the social forces required to bring such a shift about. The vacuum of data and analysis about history, politics, and social processes may lead to unrealistic expectations, or alternatively to cynicism, the view that nothing will ever change.

Activists tend to be more adept than scholars at conducting political analysis because it is a central requirement of their jobs. Some remarkable activist-scholars I have worked with in Indonesia over the years are engaged politically on multiple levels: supporting villagers in situated struggles against land seizure or eviction, pulling together different social groups and platforms into a unified front to pressure the government to 
address grievances, and persuading politicians and officials that they too would be more secure and prosperous if the most egregious injustices were addressed. They embrace the educative role of the intellectual as they attempt to reconstitute the hegemonic field. Their media writings are directed primarily toward their own class, as they seek to shift the boundaries of what fellow newspaper readers accept as normal, and shame them out of their indifference. They also prepare detailed critiques of unjust laws, policies, and programs of intervention, challenging the programmers' monopoly on the production of authoritative knowledge. Anthropologistsas-critics may be able to contribute to the efforts of scholar-activists. Whatever its source, Foucault suggests that critique is productive when it works as "an instrument for those who fight, those who resist and refuse what is." (Foucault, 1991b : 84).

Change does occur. The taming of capitalism in the form of the welfare state in post-war Europe is one example. It was not the result of planning alone, though planners had a role. It took different forms in different national spaces, each with its own constellation of social forces. It was a political settlement that lasted thirty years, roughly 1948-78, during which the conditions of life for the lowest third of the population improved significantly, and the gap between rich and poor declined. Right now, we're headed in the opposite direction, with stunning levels of inequality both within and between nations, and a new war on the poor. Yet there are counter-tendencies. Anthropological research is again relevant: we don't need to generalize or be grandiose, but rather to ask - precisely and specifically - if something progressive is happening, why is it happening here? Why now? Why in this form, and not another? (Li, 2009; Ferguson, 2009). Conversely, if what is emerging is impoverishment and abandonment, or violence and xenophobic attack, anthropologists can seek to explain this: what are the social and cultural configurations that enable these tendencies, or render them acceptable? What are the spatial configurations, the flows of information, the stories that people tell, the popular schemes for separating the deserving from the undeserving, the citizen from the alien, us from them? This kind of anthropology focuses on what is emerging, and in so doing it puts programming in its place as only one of the social forces changing our world. We should pay attention to programming because it 
has effects, but we should not place it center stage because it isn't necessarily the most important element in the constellation.

What then are the tensions associated with fieldwork of this kind - research that we might do "in the context of development or emergency" but not centered on intervention? The usual tension is over relevance. Programmers, and critics closely involved with programming, often don't see the point of what they might call "pure" or "scientific" research. They don't see it as useful. If a report doesn't end with a conclusion that says: therefore the government should do $x$, or the policy should be $y$, or the answer is $z$, they think it has no value. Hence it can be difficult to fund this kind of research, especially in contexts where development agencies are the principal or only source of research funds. Governments - including the Canadian government - are reducing the funds for "pure" research in favour of research that can be applied or instrumentalized. This is a huge constraint. It can also produce tensions in fieldwork. Villagers may ask: if you are not here to help us, or bring us projects, or give us money or jobs, why are you here? Parts of the world that have been saturated by development programming, and by instrumental research, have become difficult territories for ethnographic research that is opened ended, and seeks to explore emergent patterns of politics and social change without attaching them to prescriptions.

\section{Conclusion}

I have distinguished three types of anthropological engagement with development: anthropology in support of programming, anthropology as critique, and anthropology as the study of social processes and emergence. Each has tensions intrinsic to it, and there are gulfs between them that cannot or should not be breached. I'm not arguing that one type of practice is superior to the other two, or should replace them. I'm arguing that recognizing their distinct character helps us to understand the kinds of knowledge, fieldwork relations, and tensions peculiar to each.

A programmer cannot be simultaneously a critic, nor can she make full use of her knowledge of the social forces shaping the world: she has to draw a boundary and render problems technical in order to do her job. A 
critic is focused on exposing the deficiencies of programs, puncturing their boundaries, and challenging complacency, but there is a limit to this exercise: at the end of the day, programming requires closure and a critic's input will either be absorbed or dismissed. Studies of emergence don't result in programs of intervention because their focus is the specificity of the conjuncture and the political, economic and social relations that form it. Those relations are peculiar to their time and place, and can't be replicated; nor is it easy to harness or control them. Yet we need to study them because they are the relations that shape and change our world, for better or worse.

\section{Bibliography}

Bauman, Z., 2007, "Has the Future a Left?", Soundings 35.

Ferguson, J., 1994, The Anti-Politics Machine: "Development," Depoliticization, and Bureaucratic Power in Lesotho, Minneapolis, University of Minnesota Press.

Ferguson, J., 2009, "The Uses of Neoliberalism", Antipode 41, n S1 : 166-84.

Foucault, M., 1991a, "Governmentality", in Burchell G., Gordon C. and Miller P., The Foucault Effect: Studies in Governmentality, Chicago: University of Chicago Press : 87-104.

Foucault, M., 1991b, "Questions of Method", in Burchell G., Gordon C. and Miller P., The Foucault Effect: Studies in Governmentality, Chicago: University of Chicago Press : 73-86.

Hart, G., 2009, "D/Developments after the Meltdown.", Antipode 41, n S1 : 117-41.

Li, T.M., 2007, The Will to Improve: Governmentality, Development, and the Practice of Politics, Durham NC, Duke.

Li, T.M., 2009, "To Make Live or Let Die? Rural Dispossession and the Protection of Surplus Populations", Antipode 41, n S1 : 63-93.

Li, T.M., 2014, Land's End: Capitalist Relations on an Indigenous Frontier, Durham NC, Duke.

Mosse, D., 2005, Cultivating Development: An Ethnography of Aid Policy and Practice, London, Pluto Press. 
Tania Murray Li

Mosse, D., 2006, "Anti-Social Anthropology? Objectivity, Objection and the Ethnography of Public Policy and Professonal Communities", Journal of the Royal Anthropological Institute 12 (4) : 935-56.

Mosse, D. ed., 2011, Adventures in Aidland: The Anthropology of Professionals in International Development, New York, Berghahn.

Rose, N., 1999, Powers of Freedom: Reframing Political Thought, Cambridge, Cambridge University Press.

\section{ivisive}

Tania Murray Li is Professeur of Anthropology at the University of Toronto

E-mail : tania.li@utoronto.ca 